\title{
Hydro-Geophysical Assessment of Soil and Groundwater Near Active Dumpsites in Gusau Metroplis, Zamfara State, Nigeria
}

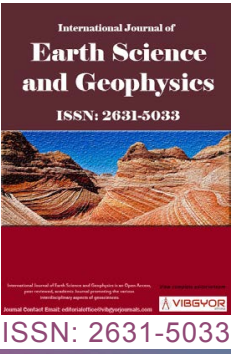

\author{
Murana $K A^{1^{*}}$, Shuaibu $A M^{1}$ and Ajibade $\|^{2}$ \\ ${ }^{1}$ Department of Geological Sciences, Federal University Gusau, Nigeria \\ ${ }^{2}$ Department of Physics, Federal University Gusau, Nigeria
}

\begin{abstract}
Soil and groundwater pollutions are worldwide phenomena which result from both natural and anthropogenic sources. In this research, geophysical investigations involving geoelectric survey using ABEM SAS 300 Terrameter was carried out around three active dumpsites in Gusau, Northwestern, Nigeria for hydro-geophysical assessment of the contamination of soil and groundwater. Vertical electrical Soundings (VES) were conducted on the dumpsites by using Schlumberger array with maximum current electrode separations of $180 \mathrm{~m}$. Five VES were conducted on each dumpsite making a total of fifteen VES along three profiles. The field data obtained has been analyzed using WinGlink software which gives an automatic interpretation of apparent resistivity. The VES results revealed three subsurface layers. The geologic sequence beneath the study area is composed of topsoil (clay to sandy-clay, sandy-lateritic), weathered basement, fractured basement and fresh basement.The topsoil has resistivity ranging from 1.5 $\Omega \mathrm{m}$ to $48.2 \mathrm{~m} \Omega$ while the thickness vary from $0.47 \mathrm{~m}$ to $3.37 \mathrm{~m}$ across the profiles. The second layer's resitivity vary from $5.4 \Omega \mathrm{m}$ to $144.35 \Omega \mathrm{m}$ and their thickness ranges from $1.36 \mathrm{~m}$ to $16.93 \mathrm{~m}$. The third geoelectric layer has resisitivity from $70.0 \Omega \mathrm{m}$ to $6003.0 \Omega \mathrm{m}$. The results revealed that the top soils in all the dumpsites were characterized by very low resistivity depicting possible pollution and contamination at all dumpsites. The dumpsites are depicted by differential decomposition of waste as zones of advanced decomposition and fresh waste are reflected by low and high resistivity respectively. The second and third layers show moderate to high resistivity values which are indicative of leachate absence. These areas are suitable for groundwater expolration. Findings from the study indicate that there may be possible contamination of shallow groundwater system in the nearest future if proper mitigation measures are not taken into consideration at the dumpsites.
\end{abstract}

\section{Introduction}

The environment has over the years faced adverse natural and anthropological challenges including over population, rapid loss of biodiversity, global warming and waste management.
Solid wastes are produced on daily basis as a result of direct consequence of inevitable human activities. Refuse contents consist of various kinds of materials like metallic, organic and non-biodegradable materials [1]. The intensity of the human activities has led to increasing volume of solid

*Corresponding author: Murana KA, Department of Geological Sciences, Federal University Gusau, Zamfara State, Nigeria

Accepted: November 18, 2019; Published: November 20, 2019

Copyright: (C) 2019 Murana KA, et al. This is an open-access article distributed under the terms of the Creative Commons Attribution License, which permits unrestricted use, distribution, and reproduction in any medium, provided the original author and source are credited.

Murana et al. Int J Earth Sci Geophys 2019, 5:028

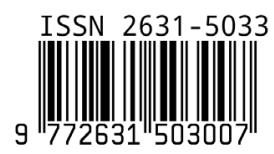


waste worldwide despite the current level of global technological advancement and industrilization [2-4]. Poor management of solid waste has resulted to a lot of disastrous effects such as aesthetics, environmental hazard and pollution. Arbitrary refuse dumping pose a serious threat of polluting soil, groundwater and downstream surface water. Pollution of soil by leachate from surrounding minicipal waste dumps has been recognised for a long time [5-8].

The waste disposal sites in Gusau are uncontrolled open dumps, thus creating serious heath and environmental threats. Studies have shown that soil and groundwater systems can be polluted due to poorly designed waste disposal facilities, leakage from underground storage tanks and agricultural waste. Soil and groundwater acidification and nitrification have been linked to waste dumps [9] as well as microbial contamination of soil and groundwater system $[10,11]$ attributed cancer, heart diseases and teratogenic abnormalities to grounndwater contamination via leachate from waste dumps.

The management of solid waste landfills has been a major problem in Nigeria as well as other developing nations worldwide. Solid waste managements in Nigeria is characterized by inefficient collection methods, insufficient coverage of the collection system and improper disposal of solid waste $[12,13]$. Wastes are generated daily and disposed indiscriminately in land and rivers without recourse to the underground environment, local geology and proximity to the residential houses.

Gusau, being the state capital is characterized by beehive of activities as a result of farming activities, banking and communication sectors, and other economic activities. Gusau has witnessed an upsurge in population over the years [14], this has led to generation of huge masses of diverse wastes. As a result, wastes are dumped on open ground which may constitute environmental and health problems. Consequently, Gusau metroplis may face critical problem pertaining to its groundwater resources if the problem of waste disposal which litters the town is not adequately addressed.

In this study, resistivity survey using Schlumberger array was carried out at three dumpsites in Gusau to assess the impact of leachate on the environment, soil and estimate the harm done to the soil as well as ascertaining the groundwater quality in the area. Earth materials are either resistive or conductive. Materials found at dumpsites which have been infilterated by chemical from biodegradable wastes have resistivities or conductivities greatly altered by the migrating chemicals. Since direct resistivity method of electrical prospecting exploits the resistivity of the earth materials, as an anomally, it is therefore one of the most suitable geophysical methods for the intended study.

\section{Description of the study areas}

Three dump sites within Gusau were selected for the study. The first dumpsite was Hiran DeKodi, Church pan which is located within latitude $12^{\circ} 09^{\prime} 57.7^{\prime \prime} \mathrm{N}$ to $12^{\circ} 09^{\prime} 59.4^{\prime \prime} \mathrm{N}$ and longitude $6^{\circ} 41^{\prime} 9.2^{\prime \prime} \mathrm{E}$ to $6^{\circ} 41^{\prime} 11.5^{\prime \prime} \mathrm{E}$. The second site was Gangare Yarima close to Bye-pass which is located within latitude $12^{\circ} 10^{\prime} 50.5^{\prime \prime} \mathrm{N}$ to $12^{\circ} 10^{\prime} 51.9^{\prime \prime} \mathrm{N}$ and longitude $6^{\circ} 41^{\prime} 1.1^{\prime \prime} \mathrm{E}$ to $6^{\circ} 41^{\prime} 2.1^{\prime \prime} \mathrm{E}$. The third site was Ahmadu Bello way Near Bebeji area which is located within latitude $12^{\circ} 10^{\prime} 11.5^{\prime \prime} \mathrm{N}$ to $12^{\circ} 10^{\prime} 514.1^{\prime \prime} \mathrm{N}$ and longitude $6^{\circ} 39^{\prime} 51.7^{\prime \prime} \mathrm{E}$ to $6^{\circ} 39^{\prime} 53.8^{\prime \prime} \mathrm{E}$. The elevation in the study areas varies between $451 \mathrm{~m}$ to $454 \mathrm{~m}$ above mean sea level.

The area is within the tropical Sananna climate with distinct dry and wet seasons. The hottest months in Gusau are March and April, which is just before the first rainfall (the highest temperature is about $41{ }^{\circ} \mathrm{C}$ ). The lowest temperature of $25^{\circ} \mathrm{C}$ is in January, at the peak of Harmattan or in August during rainy season. The mean annual rainfall in Gusau is between $850-1350 \mathrm{~mm}$. The onset of the rain on the average is between mid-April and May, lasting for about six months till the end of October [15].

The study areas are underlain by different lithological units which are crystalline in nature and belong to the Basement complex rock suites, mostly the oldest being Pre-cambrian in age. From the field mapping exercise Migmatite, Banded gneiss, Quartzite, Mica schists, Phyllites, Granites and minor intrusion of pegmatites were the rock types found underlain the study area (Figure 1).

\section{Theories of Electrical Resistivity Survey}

The D.C. resistivity method is based on the fact that when current $(I)$ is driven into the earth, any variation of the subsurface resistivity will alter the current flow which will in turn affect the distribution of the electric potential. The measurement of the electric potential and the current especially on 


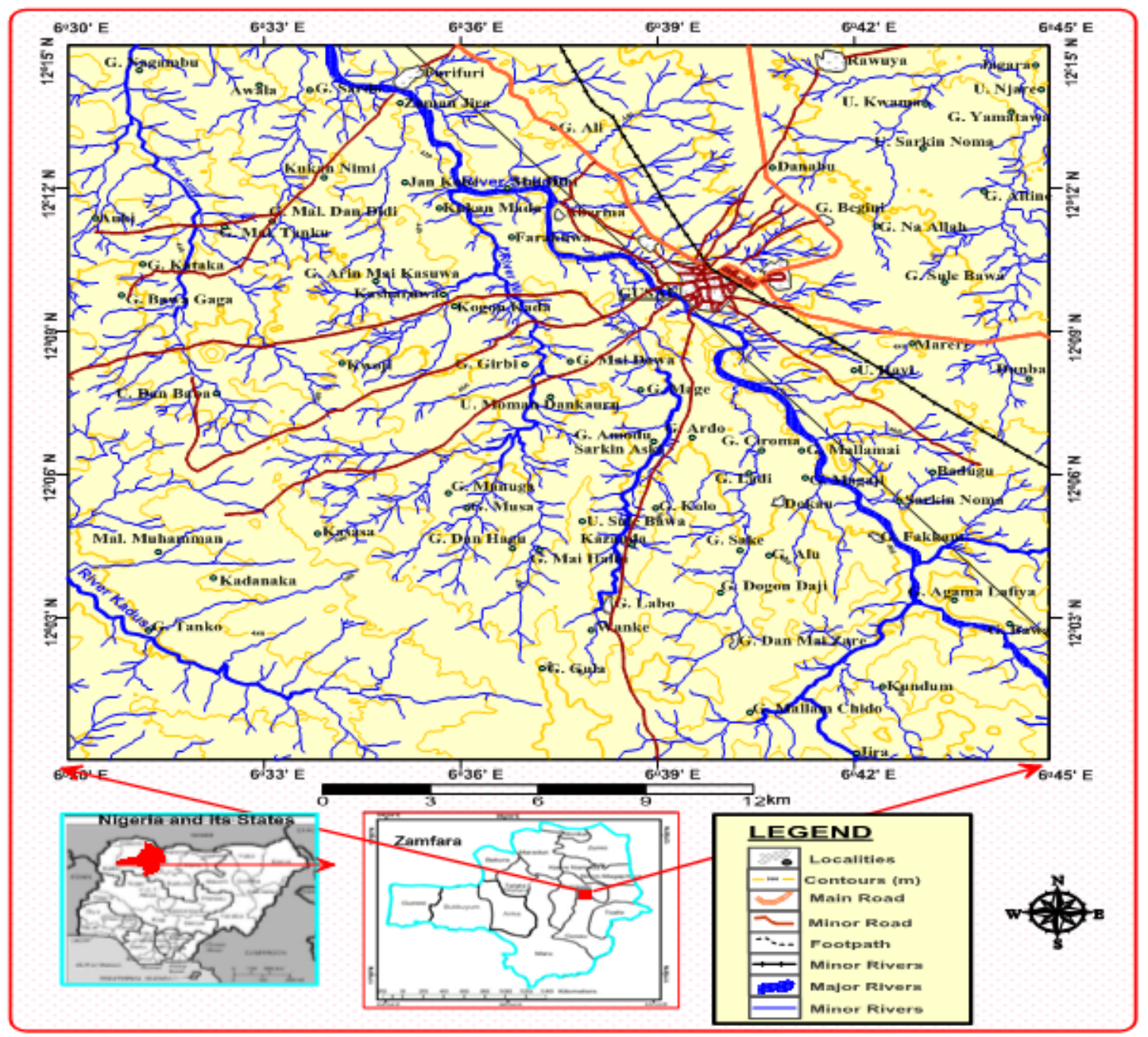

Figure 1: Map of the study area.

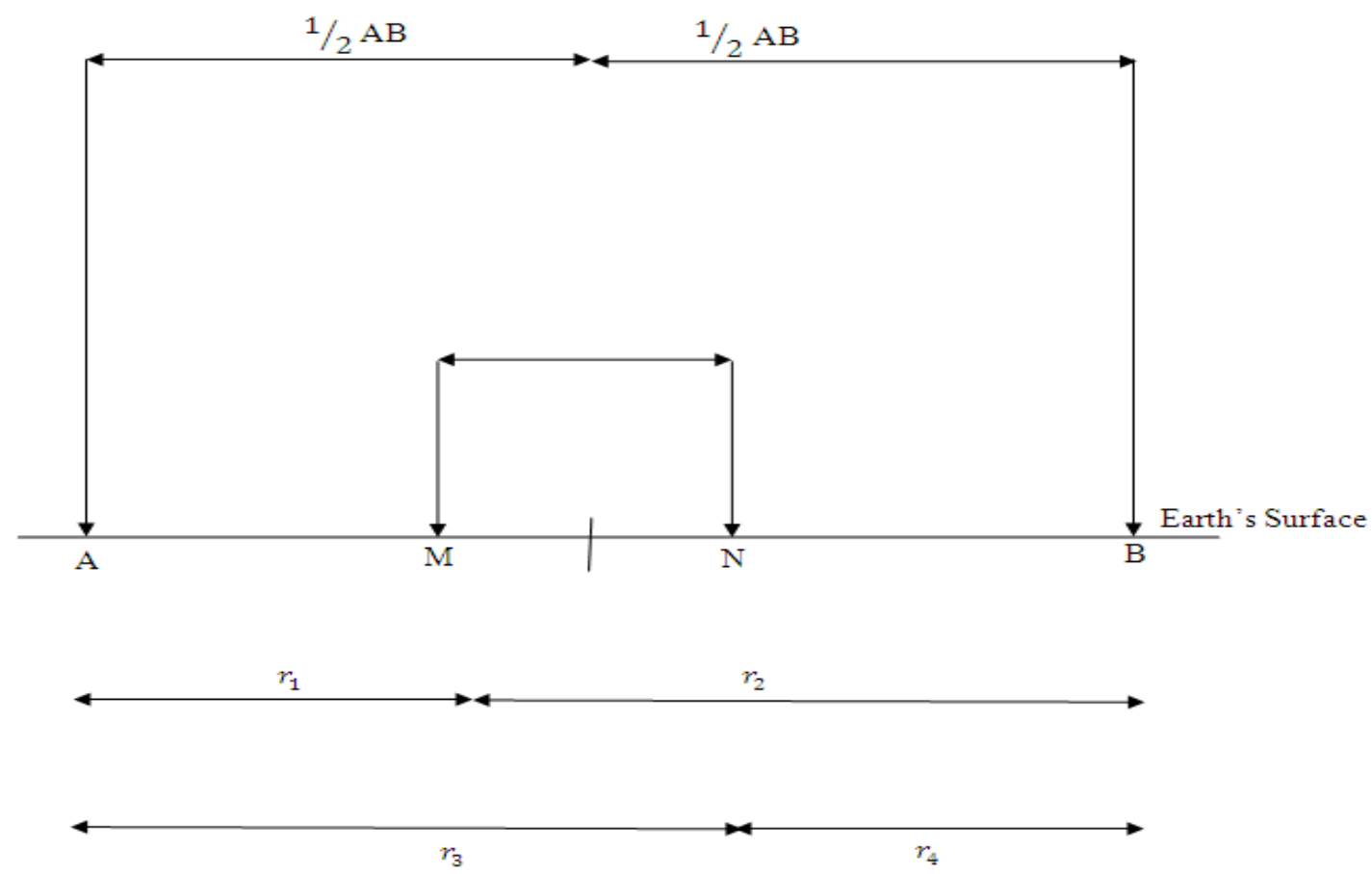

Figure 2: Schematic diagram of Schlumberger array. 
the earth surface makes it to obtain information about the resistivity variation of the subsurface in the area concerned [16].

In the Schlumberger array employed, the four electrodes are positioned on a straight line, with the two current electrodes on the outside of the potential measuring electrodes. The interpretation of the Vertical electrical sounding (VES) data is based on the assumption that the subsurface consists of a sequence of distinct layers of finite thickness and each of these layers is assumed to be electrically homogenous and isotropic [17] and the boundary planes between subsequent layers are assumed to be horizontal. Figure 2 is a schematic illustration of the Schlumberger array which is used for the survey.

Where $A$ and $B$ are electrodes through which current is driven into the ground while $\mathrm{M}$ and $\mathrm{N}$ are two potential electrodes (to record the potential distribution in the subsurface). The principle underlying the resistivity method is embodied in Ohm's law.

From Ohm's law, the current I and potential difference $V$ in a metallic conductor at constant temperature are related as follows:

$V=I R$

$\mathrm{R}$ is the constant of proportionality termed resistance measured in ohms.

The resistance $\mathrm{R}$ of a conductor is related to its length $L$ and cross sectional area $A$ by:

$$
\mathrm{R}=\frac{\rho L}{A}
$$

Where $\rho$ is the resistivity and it is the property of the material considered.

From equations ( 1 ) and ( 2 ),

$$
\mathrm{V}=\frac{\mathrm{I} \rho \mathrm{L}}{\mathrm{A}}
$$

For simple treatment, a semi-infinite solid with uniform resistivity, $\rho$, is considered. A potential gradient is measured between $\mathrm{M}$ and $\mathrm{N}$ when current $I$ is introduced into the material through $A$ and $B$ on the surface. The surface area is $2 \pi L^{2}$. Thus equation (3) becomes:

$$
\mathrm{V}=\frac{\mathrm{I} \rho}{2 \pi \mathrm{L}}
$$

By deduction then, the potential at $M\left(V_{M}\right)$, due to the two current electrodes is:

$$
\mathrm{V}_{\mathrm{M}}=\frac{\mathrm{I} \rho}{2 \pi}\left(\frac{1}{\mathrm{r}_{1}}-\frac{1}{r_{2}}\right)
$$

Similarly, the potential at electrode $N\left(V_{N}\right)$ is given by:

$$
V_{N}=\frac{I \rho}{2 \pi}\left(\frac{1}{r_{3}}-\frac{1}{r_{4}}\right)
$$

Where $r_{1}, r_{2}, r_{3}$ and $r_{4}$ are as shown in Figure 3.

Absolute potentials are difficult to measure [18] so the potential difference $\Delta \mathrm{V}$ between $\mathrm{M}$ and $\mathrm{N}$

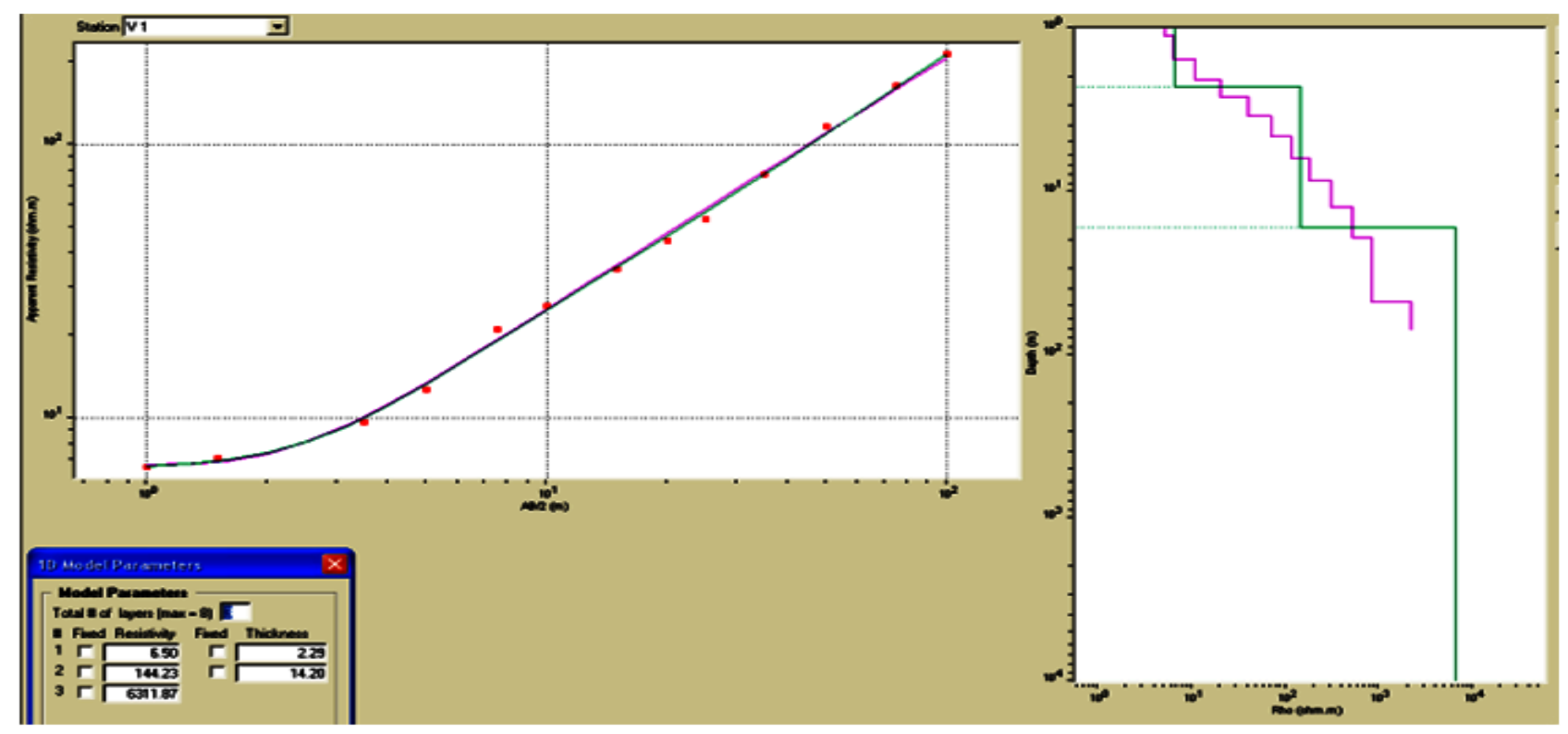

Figure 3: Shows the typical sounding curve. 
is measured. When the subsurface is inhomogeneous, apparent resistivity $\rho_{a}$ is considered.

Thus:

$\Delta V=\left(V_{M}-V_{N}\right)=\frac{I \rho_{a}}{2 \pi}\left\{\left(\frac{1}{r_{1}}-\frac{1}{r_{2}}\right)-\left(\frac{1}{r_{3}}-\frac{1}{r_{4}}\right)\right\}$

Then,

$$
\rho_{a}=\frac{2 \pi \Delta V}{I\left\{\left(\frac{1}{r_{1}}-\frac{1}{r_{2}}\right)-\left(\frac{1}{r_{3}}-\frac{1}{r_{4}}\right)\right\}}
$$

Where $\rho_{a}$ is apparent resistivity in ohm-metre. From equation (8),

$$
\begin{aligned}
& \rho_{a}=K\left(\frac{\Delta V}{I}\right) \\
& \text { i.e. } K=2 \pi\left[\left(\frac{1}{r_{1}}-\frac{1}{r_{2}}\right)-\left(\frac{1}{r_{3}}-\frac{1}{r_{4}}\right)\right]^{-1}
\end{aligned}
$$

where $K$ is the geometric factor in metre which depends on the electrode array used.

For Schlumberger array, if $M N=b$ and $1 / 2 A B=a$ then,

$$
K=\pi\left(\frac{a^{2}}{b}-\frac{b}{4}\right)
$$

\section{Materials and Methods}

Two dimensional (2D) electrical resistivity surveys were carried out on the dumpsites using ABEM
SAS 300 systems in December, 2018. The resistivity survey was completed with 15 sounding stations. Either N-S or E-W profile was taken at each single vertical electrical sounding (VES) point. The VES involves injecting an artificially generated direct current or very low frequency alternating current into the ground through two electrodes. The resulting potential difference is measured by another pair of potential electrodes in the vicinity of the current flow. The field data acquisition was carried out by moving two or four of the electrodes used, between each measurement, following the technique outlined by $[16,18]$. The VES was conducted by using the Schlumberger array with a maximum current electrode spacing (AB) of $180 \mathrm{~m}$.

The widest current electrode spacing used was $180 \mathrm{~m}$, that is, $1 / 2 A B=90 \mathrm{~m}$. According to [19], the maximum depth of penetration in Schlumberger array is $0.19 \mathrm{AB}$. The potential electrode separation, $\mathrm{MN}$, was also increased intermittently in order to maintain a measurable potential, but it did not exceed one-fifth of the half-current electrode separation, $1 / 2 A B$, as suggested by [20].

Table 1: Resistivity values adopted for this work [29].

\begin{tabular}{|l|l|}
\hline Sampled Materials & Resistivity range $(\mathbf{\Omega m})$ \\
\hline Clay & $1-20$ \\
\hline Clayey Sand and Sandy Clay & $30-100$ \\
\hline Weathered Basement & $100-300$ \\
\hline Fractured Basement & $300-900$ \\
\hline Fresh Basement & $>1000$ \\
\hline
\end{tabular}

Table 2: Resistivity values [24].

\begin{tabular}{|l|l|}
\hline Sampled Materials & Resistivity $\mathbf{( \Omega \mathbf { m }} \mathbf{~}$ \\
\hline Leachate only & 2.994 \\
\hline Sand saturated with leachate & $4.97-5.04$ \\
\hline Fresh water (plant materials, rubber strans) with saturated with leachate & $6.03-7.16$ \\
\hline Soil saturated with leachate & $3.15-4.00$ \\
\hline Rain water only & 73.88 \\
\hline Sand saturated with rain water & $14.36-17.50$ \\
\hline Fresh waste (plant materials, rubber strands) saturated with rain water & $9.30-10.57$ \\
\hline Clay saturated with rain water & $9.30-10.57$ \\
\hline Clay saturated with brackish water & $0.12-0.20$ \\
\hline Clean sand saturated with sea water & $1.5-3.5$ \\
\hline Fresh sand stone & 600 \\
\hline Phyllite & 300 \\
\hline Hard rock & $>600$ \\
\hline
\end{tabular}


Measurements were taken at expanding current electrodes distances such that in theory, the injected electrical current should be penetrating at greater depth. The Terrameter gave values of resistance (ohms) from where the values of apparent resistivity were calculated using equation 9 above. The field data was interpreted by applying partial curve matching technique [17] with the help of master curves $[15,21]$. From the preliminary interpretation, initial estimates of the resistivity and thickness of the various geoelectric layers at each VES locations were determined. These geoelectric parameters were then employed as starting models for the computer-aided iteration using WinGlink software.

In the interpretation stage, resistivity values gotten from the sounding curves were discussed based on the resistivity values of rock types similar to the study area (Table 1) and compared to resistivity values obtained from laboratory measurements for landfill and other earth materials (Table 2).

\section{Data processing}

Geoelectric data acquired were processed to remove noise arising from instrumentation and environmental influence. The apparent resistivity data were presented as sounding curves. The curves were obtained by plotting the apparent re- sistivity values against half of the current electrode separations $(A B / 2)$ on log -log graphs that have the same modulus as that of the 2-layer master curves. The curve type in each VES station depends on the subsurface layers sequence. The main purpose of processing the VES data displayed as curves is to determine the subsurface layers, their resistivities, as well as their thicknesses. These were achieved through utilization of WinGlink software for processing the acquired data.The processed data were presented as 1-D iteration models and geoelectric sections.

\section{Results and Discussion}

From the 1D-resistivity curves, the interpreted layer parameters for each dumpsite are summarized below. For better understanding, the results of investigation are presented in form of geoelectric sections. However, the top soil and weathered basement are regarded as the overburden while the bedrock consists of the fracture and the fresh basement rocks [22]. The modelling of VES measurements carried out at the fifteen (15) stations has been used to derive geoelectric sections for the profiles (Figure 4, Figure 5 and Figure 6). The interpreted layer parameters for the three dumpsites are presented in Table 3, Table 4 and Table 5 below. The geolectric and geologic sections were

\section{Geological and Geoelectrical Sections}

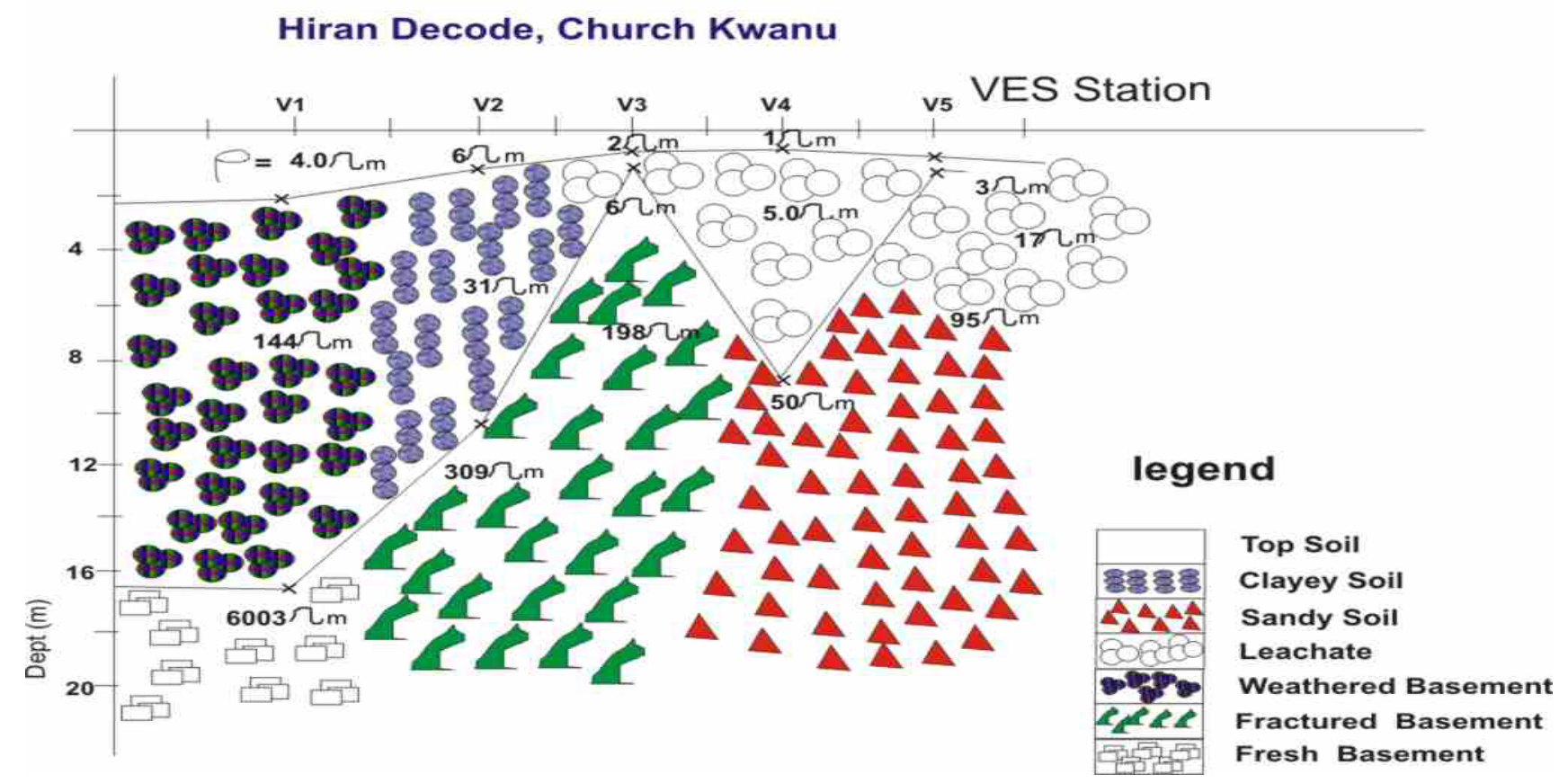

Figure 4: Geoelectric Section at Hiran Decodi, Church Kwanu Dumpsite, Gusau. 


\section{Geological and Geoelectrical Sections}

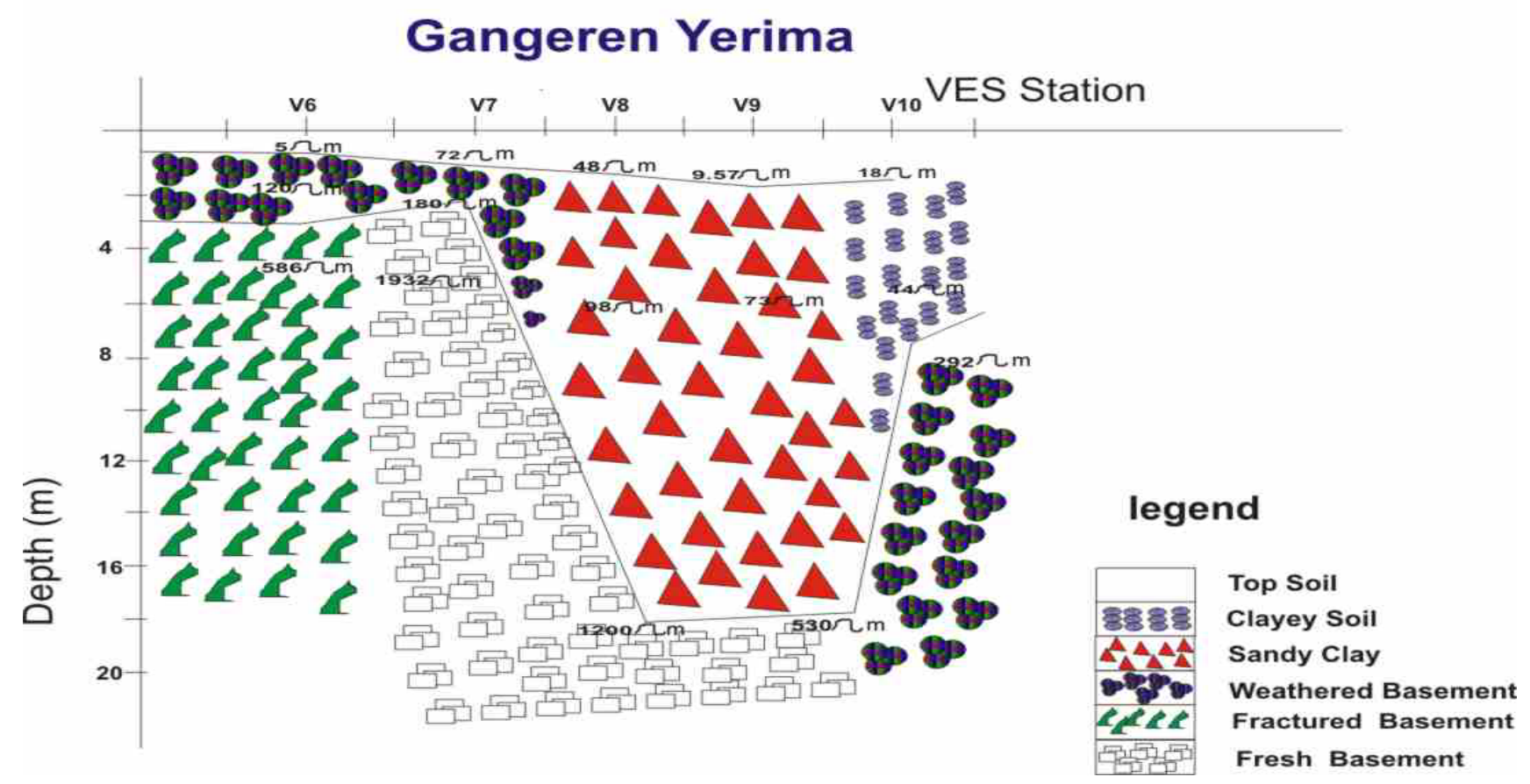

Figure 5: Geoelectric section at Gangeren Terima Dumpsite, Gusau.

\section{Geological and Geoelectrical Sections}

\section{Bebeji Area}

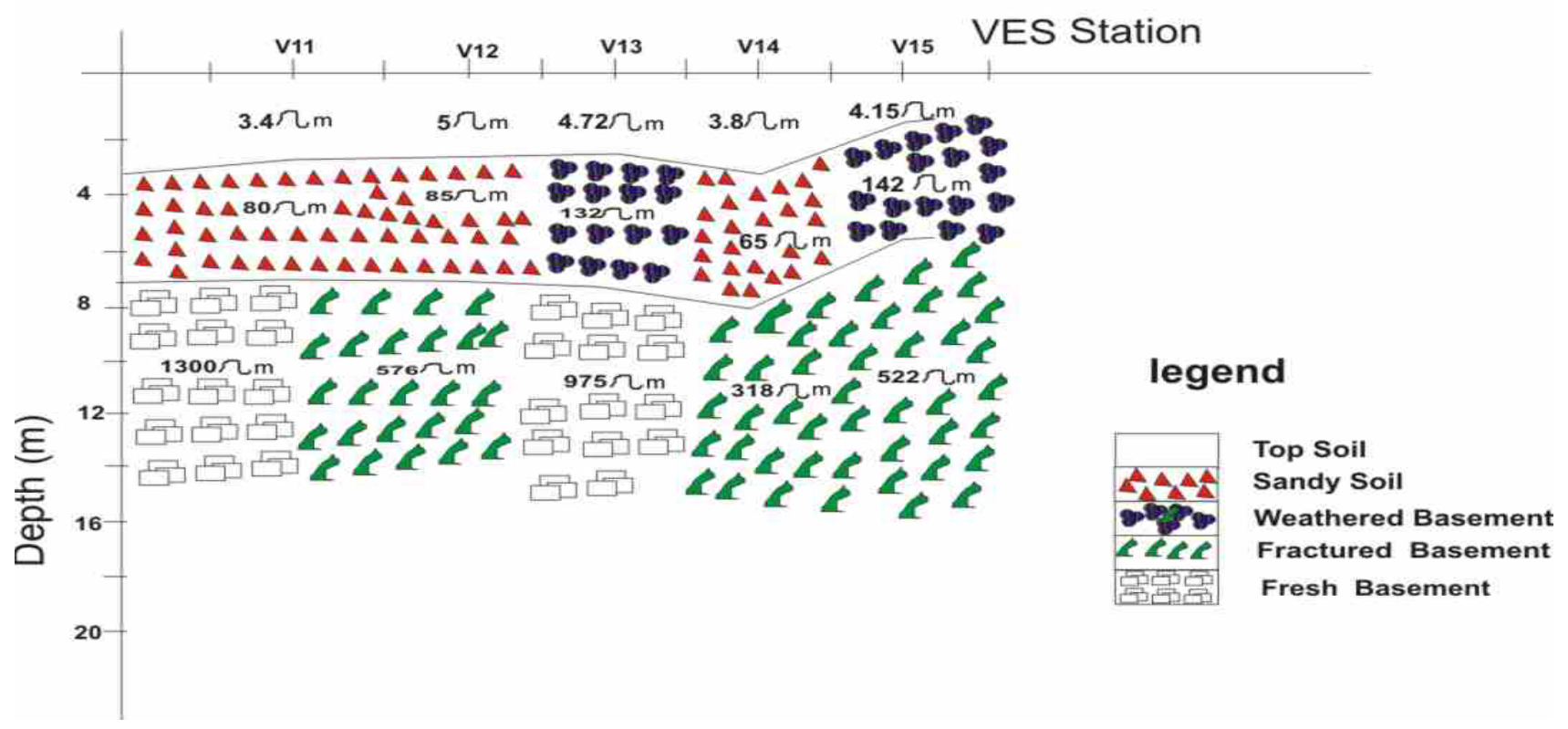

Figure 6: Geoelectric section at Bebeji Area Dumpsite, Gusau.

plotted with the aid of Autocard. The geoelectric sections of the study area were generated to show the vertical variation of the material in relation to their resistivities values.

\section{Discussion of findings at Hiran Decode Dump- site}

The geoelectric sections of this dumpsite consist of five VES points from VES 1 to 5 . The area has 
Table 3: Interpreted layer parameter for Hiran Decode Dumpsite, Church Pan Area.

\begin{tabular}{|c|r|l|l|l|}
\hline VES Station & Layer & Resistivity $(\Omega \mathrm{m})$ & Thickness $(\mathbf{m})$ & Depth $(\mathbf{m})$ \\
\hline $\mathbf{1}$ & 1 & 6.50 & 2.29 & 2.29 \\
& 2 & 144.35 & 14.2 & 16.49 \\
\hline $\mathbf{2}$ & 3 & 6003.00 & & 1.58 \\
& 1 & 4.50 & 1.58 & 10.36 \\
\hline $\mathbf{3}$ & 2 & 31.40 & 8.78 & 1.29 \\
& 3 & 309.10 & & 5.81 \\
\hline $\mathbf{4}$ & 1 & 2.50 & 1.29 & \\
& 2 & 14.00 & 4.52 & 0.68 \\
& 3 & 198.00 & & 8.64 \\
\hline 5 & 1 & 1.50 & 0.68 & 0.74 \\
\hline & 2 & 5.40 & 7.96 & 2.10 \\
\hline
\end{tabular}

Table 4: Interpreted layer parameter for Gangare Yarima Dumpsite.

\begin{tabular}{|c|c|c|c|c|}
\hline VES Station & Layer & Resistivity $(\Omega \mathrm{m})$ & Thickness (m) & Depth (m) \\
\hline \multirow{3}{*}{6} & 1 & 5.00 & 0.47 & 0.47 \\
\hline & 2 & 120.00 & 2.62 & 3.09 \\
\hline & 3 & 586.00 & & \\
\hline \multirow{3}{*}{7} & 1 & 72.00 & 0.58 & 0.58 \\
\hline & 2 & 180.00 & 1.68 & 2.26 \\
\hline & 3 & 1932.10 & & \\
\hline \multirow{3}{*}{8} & 1 & 48.20 & 1.28 & 1.28 \\
\hline & 2 & 98.14 & 16.93 & 18.21 \\
\hline & 3 & 1200.00 & & \\
\hline \multirow{3}{*}{9} & 1 & 9.57 & 1.64 & 1.64 \\
\hline & 2 & 73.40 & 16.47 & 18.11 \\
\hline & 3 & 530.0 & & \\
\hline \multirow{3}{*}{10} & 1 & 18.40 & 1.25 & 1.25 \\
\hline & 2 & 44.50 & 6.14 & 7.39 \\
\hline & 3 & 292.60 & & \\
\hline
\end{tabular}

three subsurface layers as depicted in Figure 4. The first layer is the top soil which is characterized by very low resistivity values ranging from $1.5 \Omega \mathrm{m}$ to $6.5 \Omega \mathrm{m}$ across the profile (Table 3 ). The thicknessses of this layer range between $0.68 \mathrm{~m}$ to $2.29 \mathrm{~m}$. The topsoil might be polluted due to low resistivity values whose lithology according to Table 2 above is leachate. The second layer has resisitivity ranging from $5.4 \Omega m$ to $144.35 \Omega m$ with thicknesses from
$1.36 m$ to $14.2 m$ The lithology of this layer as evidenced on Table 1 above might range from clay to sandy clay. However, no such thickness of clay has been reported in the area from the available borehol data. The infiltration of contamination plumes was due to the high porosity and permeability that characterizes the soil present in the study area. The third subsurface layer has resistivities that range from $70 \Omega m-6003 \Omega m$. So, based on theporosity 
Table 5: Interpreted layer parameter for Bebeji dumpsite.

\begin{tabular}{|c|c|c|c|c|}
\hline VES Station & Layer & Resistivity ( $\Omega \mathrm{m})$ & Thickness (m) & Depth (m) \\
\hline 11 & $\begin{array}{l}1 \\
2 \\
3\end{array}$ & $\begin{array}{l}3.40 \\
80.00 \\
986.00\end{array}$ & $\begin{array}{l}3.38 \\
3.80\end{array}$ & $\begin{array}{l}3.38 \\
7.18\end{array}$ \\
\hline 12 & $\begin{array}{l}1 \\
2 \\
3\end{array}$ & $\begin{array}{l}5.00 \\
85.00 \\
572.10\end{array}$ & $\begin{array}{l}0.58 \\
1.68\end{array}$ & $\begin{array}{l}0.58 \\
2.26\end{array}$ \\
\hline 13 & $\begin{array}{l}1 \\
2 \\
3\end{array}$ & $\begin{array}{l}4.72 \\
132.14 \\
975.00\end{array}$ & $\begin{array}{l}1.28 \\
16.93\end{array}$ & $\begin{array}{l}1.28 \\
18.21\end{array}$ \\
\hline 14 & $\begin{array}{l}1 \\
2 \\
3\end{array}$ & $\begin{array}{l}3.8 \\
65.50 \\
315.50\end{array}$ & $\begin{array}{l}1.64 \\
16.47\end{array}$ & $\begin{array}{l}1.64 \\
18.11\end{array}$ \\
\hline 15 & $\begin{array}{l}1 \\
2 \\
3\end{array}$ & $\begin{array}{l}4.15 \\
142.50 \\
522.50\end{array}$ & $\begin{array}{l}1.25 \\
6.14\end{array}$ & $\begin{array}{l}1.25 \\
7.39\end{array}$ \\
\hline
\end{tabular}

and permeability conditions of the observed geologic materials in the area, the result shows that VES 2-5 of the Hiran Decodi dumpsite has been polluted by leachate. The extremely low resitivity values in this layer suggest the contamination plume zone in the area [23]. It is interesting to note that at VES 1, fresh basement was encoured from depth of about $16 \mathrm{~m}$. The results of this investigations show that both the soil and groundwater at this dumpsite have been contaminated.

\section{Discussion of findings at Gangeren Yerima Dumpsite}

The results of the investigation show that three subsurface layers exist in this site. The dumpsite consists of VES 6 to 10. The top soil resistivity values ranging from $5.0 \Omega \mathrm{m}$ to about $72 \Omega \mathrm{m}$ and thicknesses varying from $0.47 \mathrm{~m}$ to $1.64 \mathrm{~m}$. The lithology of the first layer is majorly clay. The low resistivity values at the top soil is an indication of leachate at the layer. The second subsurface layer delineated has resistivity and thickness values varying from 44 $\Omega m$ to $180 \Omega m$ and $1.58 m$ to $16.47 m$ respectively. The third subsurface layer's resistivity ranges from $292 \Omega \mathrm{m}$ to $1932 \Omega \mathrm{m}$. The results of this investigation show that at Gangeren Yerima dumpsite site, apart from topsoil at VES 6 (Table 4) which has low resistivity of $5.0 \Omega \mathrm{m}$ indicating leachate, there is absence of leachate contamination from this dumpsite. The high resistivity response in this zone is evident that the soil and groundwater are safe for exploitation.

\section{Discussion of findings at Bebeji Dumpsite}

This geoelectric section consists of VES from point 11 to 15 . Three subsurface layers are delineated. The resistivity of the first layer across the VES points are generally low ranging from $3.4 \Omega \mathrm{m}$ to $5.0 \Omega \mathrm{m}$ which is an indication of leachate contamination (Table 2) at topsoil across this profile. The second layer has resitivity values and thicknesses that varies from $65.50 \Omega \mathrm{m}$ to $142.50 \Omega \mathrm{m}$ and $3.42 \mathrm{~m}$ to $4.32 \mathrm{~m}$ respectively (Table 5 ). The third geoelectric layer has resistivity ranging from $315.5 \Omega \mathrm{m}$ to $986.0 \Omega \mathrm{m}$. The lithology at this dumpsite ranges from clay, sandy soil, weathered basement, fractured basement up to fresh basement. At VES 11, the bedrock is encoutered form depth of $7.18 \mathrm{~m}$. At other sounding points around this dumpsite, the high resistivity response of this zone is an indication that the area is free from leachate contamination and hence suggestive that the area is safe for groundwater development [24-31].

\section{Conclusion}

The study revealed that the dumpsites consist of topsoil, clayey soil, sandy clay, weathered basement, fractured basement, fresh basement which are indications that the dumpsites are located on the aquiferous zones. Results from the 
analysis of data revealed that leachate generated by surface water percolating through the waste has polluted and contaminated the topsoil in all the dumpsites as depictedby low resisitivity values. Apart from Hiran Decodi dumpsite where there is strong evidence of contamination due to low resisitivity response, the other two dumpsites showed high resistivity response in many VES points which implied that the areas are free from leachate contamination and hence suitable for groundwater development.The survey has successfully mapped the contaminant leachate plume and characterized the dumpsite in terms of subsurface resistivity distribution of leachate. The heterogeous nature of the dumpsites and the complexity of its subsurface condition require that effective remediation measures be put in place to reduce environmental hazards from dumpsite. There may also be possible contamination of shallow groundwater within the dumpsites in years to come due to porous geologic materials.

\section{Recommendations}

It is recommended that leachate samples be collected to really ascertain its composition. Physical, Chemical and microbiological assessment can be done to test for quality of the groundwater in comparison to WHO standard.

\section{Acknowledgement}

The research team wishes to express their gratitude to the Tertiary Institution Fund (TetFund), Nigeria for the sponsorship of this ongoing work under the subheading. "TETFUND/DESS/UNI/ GUSAU/2017/RP/VOL.1".

\section{Conflict of Interest}

There is no conflict of interest associated with this research.

\section{References}

1. Sunmonu LA, Olafisoye ER, Adagunodo TA, Ojoawo IA, Oladejo OP (2012) Integrated geophysical survey in a refuse dumpsite of aarada, ogbomoso, southwestern Nigeria. IOSR Journal of Applied Physics 2: 11-20.

2. Ganiyu SA, Badmus BS, Oladunjoye MA, Aizebeokhai AP, Plurin OT (2015) Delineation of leachate plume migration using electrical resistivity imaging on lapite dumpsite ibadan, southwestern Nigeria. Geosciences 5: 70-80.
3. Abdullahi NK Osazuwa IB, Sule PO (2011) Application of integrated geophysical techniques in the investigation of groundwater Contamination. A case study of municipal solid waste leachate. Ozean Journal of Applied Sciences 4: 7-25.

4. Akankpo AO, Igboekwe MU (2011) Monitoring groundwater contamination using surface electrical resistivity and geochemical methods. Journal of Water Resource and Protection 3: 318-324.

5. Banar M, Aysun O, Mine K (2006) Characterization of the leachet in an urban landfill by physiochemical analysis and solid phase microextraction-GC/MS. Environ Monitor Assess 121: 439-459.

6. Alloway BJ (1990) Heavy metals in soil. John Wiley and Sons Inc, New York, 339.

7. Lin YP, Teng TP, Chang TK (2002) Multivariate analysis of heavy metal pollution and landscape in Changhua Country in Taiwan. Landscape Urban Planning 62: 19-35.

8. Tahri M, Benyaïch F, Bounakhla M, Bilal E, Gruffat JJ, et al. (2005) Multivariate analysis of heavy metals in soils, sediments and water in the region of Meknes, central Morocco. Environ Monit Assess 102: 405417.

9. Bacud F, Sioco F, Majam J (1994) A descriptive study of the water quality of drinking wells around Payatas dumpsite. Unpublished B.Sc Thesis, University of the Philippines College of Public Health, 12-24.

10.Awomeso JA, Taiwo AM, Gbadebo AM, Arimor AO (2010) Waste disposal and Pollution management in urban areas: A workable remedy for the environment in developing countries. America Journal of Environmental Sciences 6: 26-32.

11.Sia Su GL (2008) Assessing the effects of a dumpsite to groundwater quality in Payatas, Philippines. American Journal of Environmental Sciences 4: 276280.

12. Ogwueleka TO (2003) Analysis of urban solid waste in Nsukka, Nigeria. Journal of Solid Waste Technology and Management 29: 239-246.

13.Ogwueleka TO (2009) Municipal solid waste characterization and management in Nigeria. Iran J Environ Health Sci Eng 6: 173-180.

14. Murana KA, Sule P, Ahmed AL, Abraham EM, Obande EG (2011) Subsurface stratigraphy mapping using geoelectric method and its impact on development in federal college of education (Technical) Gusau, Zamfara State, Nigeria. NAFTA Scientific Journal 62: 389-395. 
15.(2001) Investors' Guide to Zamfara State. Publication by Zamfara State Investment and Property Development Company Limited, Zamfara State Government.

16.Telford WM, Geldart LP, Sheriff RC, Keys DE (1976) Applied Geophysics. London: Cambridge University Press.

17. Kunetz G (1966) Principles of DC Resistivity Prospecting. Geoexploration Monographs. Berlin: Series No 1. Gebruder Borntraeger.

18. Kearey P, Brooks M, Hill I (2002) An introduction to geophysical exploration. USA: Blackwell Publishing.

19.Barker RD (1989) Depth of investigation of collinear symmetrical four-electrode arrays. Geophysics 54: 1031-1037.

20.Dobrin MB, Savit CH (1988) Introduction to Geophysical Prospecting. (4 ${ }^{\text {th }}$ edn), New York: McGraw- Hill Book Company.

21.Keller GV, Frischknecht FC (1966) Electrical methods in geophysical prospecting. Oxford: Pergamon Press.

22.Oladapo MI (2013) Hydro-geoelectric study of ljare town southwestern Nigeria. International Journal of Water Resources and Environmental Engineering 5: 687-696.

23. Okpoli CC (2013) Application of 2D Electrical Resistivity Tomography in Landfill Site: A case study of lku, Ikare Akoko, Southwestyern Nigeria. Journal of Geological Research.

24.Adeoti L, Oladele S, Ogunlana FO (2011) Geo-electrical Investigation of Leachate impact on Groundwa- ter: A case study of Ile-Epo Dumpsite, Lagos, Nigeria. Journal of Appl Sci Environ Manage 15: 361-364.

25.Amadi AN, Olasehinde PI, Obaje NG, Unuevho $\mathrm{Cl}$, Yunusa MB, et al. (2017) Investigating the quality of groundwater from Hand-dug wells in Lapai, Niger State, North-Central, Nigeria using Physico-chemical and Bacteriological Parameters. Minna Journal of Geosciences 1: 77-92.

26.Amadi AN, Ameh IM, Yisa J (2010) The impact of dumpsite on groundwater quality in Makurdi metropolis, Benue State. Natural and Alied Journal 11: 90-102.

27.Grant FS, West GF (1965) Interpretation theory in applied geophysics. New York: Mc Graw Hill Books Company.

28. Koefoed O (1971) Geosounding principles: Measurement methods in Geochemistry and Geophysics. New York: Elsevier Publication.

29.Murana KA (2011) Geoelectric investigation of groundwater potential of federal college of education (Technical) Gusau, Zamfara State. Unpublished M.Sc. Thesis submitted to Physics Department of Ahmadu Bello University Zaria.

30. Mussett AE, Khan MA (2000) Looking into the earth: An introduction to geological geophysics. Cambridge: Cambridge University Press.

31.Zohdy AAR (1975) Authomatic Interpretation of Schlumberger Curves, using Modified Dar Zarrouk Function. USGS Geophysics 42: 811-822. 